\title{
EXCELLENCE IN LOGISTICS PERFORMANCE: THE EFFECT OF LOGISTICS CAPABILITY, INFORMATION SYSTEMS CAPABILITY AND ORGANIZATIONAL LEARNING
}

\author{
DOI: 10.17261/Pressacademia.2019.1127 \\ JMML-V.6-ISS.3-2019(2)-p.136-145 \\ Cemal Zehir ${ }^{1}$, Hacer Yildiz Ozturk ${ }^{2}$ \\ ${ }^{1}$ Yildiz Technical University, Department of Business Administration, 34349 Besiktas, Istanbul, Turkey \\ cemalzehir@gmail.com, ORCID: 0000-0003-2584-4480 \\ ${ }^{2}$ Yildiz Technical University, Department of Business Administration, 34349 Besiktas, Istanbul, Turkey \\ hacer.yldiz@gmail.com, ORCID: 0000-0002-1679-4883
}

Date Received: June 22, 2019

Date Accepted: September 18, 2019

To cite this document

Zehir, C., Ozturk, H. Y., (2019). Excellence in logistics performance: the effect of logistics capability, information systems capability and organizational learning. Journal of Management, Marketing and Logistics (JMML), V.6(3), p.136-145.

Permanent link to this document: http://doi.org/10.17261/Pressacademia.2019.1127

Copyright: Published by PressAcademia and limited licenced re-use rights only.

\begin{abstract}
Purpose- The purpose of this paper is to explore the effect of organizational learning on logistics capability and information systems capability, how this relation is affected by the mediating role of information systems capability and finally their effect on the firm performance. For this reason, we also aim to examine the effect of information systems capability on logistics capability and their effect on the overall model.

Methodology- Easy sampling method is used in order to collect survey data. Data collected from manufacturing companies that are operating in Marmara Region in Turkey. We reached 353 companies and 1035 usable surveys. Exploratory factor analysis (EFA) was conducted to see if the observed variables theoretically loaded together and reliability values were evaluated as well as regression analysis, which is to define the direction of relations. SPSS modeling technic has been used in testing the hypotheses.

Findings- Organizational learning has a meaningful effect on Information Systems capability and Logistics capability. We also found the mediating role of Information systems capability on the relationship between Organizational learning and Logistics capability. In addition, Organizational Learning positively affects firm performance through information systems capability, logistics capability and logistics perfor mance.

Conclusion- Managers, who want to have an excellence in logistics performance, should focus on creating an organization culture based on learning that is also supported by key capabilities. A successful firm performance is dependent on a successful logistics performance. In order to achieve this, companies not only must be learning oriented, but also must provide strong information systems capability as well as logistics capability. Logistics excellence is a powerful competence and source of competitive advantage especially for manufacturing companies and considered as a strategic resource that enables new strategic moves in the market.
\end{abstract}

Keywords: Logistics performance, logistics capability, information systems capability, resource based view, organizational learning. JEL Codes: M10, M15, M19

\section{INTRODUCTION}

Economic uncertainties, fast changing global dynamics, cultural interactions as well as globalization and technological innovations have literally changed the face of competition in business arena. Companies are not only competing on their products, prices or their positions in the market, but rather; they are competing on capability level in today's world which differentiate them on a very specific level compared to the past. The source of sustainable competitive advantage has been one of the most fundamental questions that is tried to be answered in strategic management area. In this context, as one of the most referred theories; Resource-based view (RBV) explains that achieving a sustainable competitive advantage mostly depends on the elements that are affecting organizations inside other than focusing on outside effects. The most important factors are resource and capability base of organizations that distinguish themselves from each other and make a difference. As Helfat and Peteraf (2003) argue, 
heterogeneous structure of companies cannot be ignored while explaining the resources and capabilities. They argue that companies cannot achieve a competitive advantage without understanding this multidimensionality of resources and capabilities.

A company's position, which allows achieving a competitive advantage amongst its competitors, depends on its idiosyncratic resources, capabilities and the relationships it establishes for the control of these capabilities. In resource-based theory, companies are considered to have a sustainable competitive advantage, if they are able to create a higher marginal value than an average firm in the sector they are in and if their strategy is not adopted and imitated by other firms. What makes the strat egy difficult to imitate is the unique and differentiated capabilities which are customized in the direction of organization's needs.

The success of companies in strategic capabilities is highly related with learning through repetition. As this concept is referred as organizational routines (Nelson and Winter, 1982), routines enable the creation of capabilities in organizations. A capability is actually based on multiple routines that are interacting with each other and an organization consists of a large network of routines (Nelson and Winter, 1982). Organizational learning addresses how organizations change as they acquire knowledge both from inside and outside of the organization (Celuch, Kasouf and Peruvemba, 2002). While its roots go back to the studies of researchers such as Argyris and Schon (1978) and Fiol and Lyles (1985), the notion of learning organizations started to appear by 80s. In the relevant literature, organizational learning is regarded as one of the key strategic capabilities for competitive advantage (Bapuji and Crossan, 2004; Santos-Vijande, López-Sánchez and Trespalacios, 2012). In our study, we develop a model indicating the effect of organizational learning on logistics capability and information systems capability.

Prior researches indicate many relations between organizational learning and information systems as well as organizational learning and logistics. In Agarwal, Krudys and Tanniru's study (1997) creating an information system organization that is learning oriented is suggested to become more adaptive and responsive to change. Andreua and Ciborrab (1996) emphasize the learning aspects of capability development and explore how information technology can contribute to it. Bell et al., (2014) suggest that applying the logistics information systems evaluation framework to an in-process external technology integration effort can facilitate organizational learning and also affect the success of this technology integration overall. Canessa, Morales and Maldifassi (2017) posit that the impact of information technologies (IT) on the performance of firms will differ depending on the main usage of the IT system with organizational learning: for exploration or for exploitation. They found a positive impact of using IT for exploitation on organizational performance. In addition, Panayides (2007) indicate that organizational learning has a positive influence on the improvement of logistics service effectiveness and firm performance. Shang (2009) found a significant positive relationship between organizational learning capability and financial performance in third-party logistics providers. Tippins and Sohi (2003) try to find an answer whether organizational learning has a significant role in determining the outcomes of IT or not. They found that organizational learning plays a significant role in mediating the effects of IT competency on firm performance.

The purpose of this paper is to explore the effect of organizational learning on logistics capability and information systems capability, how this relation is affected by the mediating role of information systems capability and finally their effect on the firm performance. While there are many researches examining organizational learning and information systems or information systems capability relationship which are mentioned above, there is a gap in the literature especially in the area of organizational learning and logistics capability relationship together. Logistics activities are one of the main activities that require a coordinated communication with other parties that are outside of the organization and information systems enable an infrastructure for this purpose as well. For this reason, we also aim to examine the effect of information systems capability on logistics capability and their effect on the overall model. We chose to conduct this research on manufacturing companies operating in the following sectors; automotive, electronic machinery and technology, textile, food, drink and tobacco, metal goods, chemical and petroleum, pharmaceutical and wood. Our research is of a big importance because there are not many researches that are analyzing capabilities and performance measures like logistics focusing on such a wide range of sectors framework. Besides, even though there are many researches indicating the relationships between organizational learning together with different capabilities; there are not many studies focusing on logistics capability and information system capabilities together. We also aim to fill this gap in the literature with our careful implementation on the manufacturing companies operating in Turkey.

We first develop a conceptual starting point for our research based on the resource-based view of the firm and explain capabilities and then organizational learning concept in detail. Thereafter, we outline the methodology for the research; after giving information about sample and data collection, we explain our research model and related hypotheses. Our analyses are discovered empirically and explained in findings. Finally, conclusions are drawn and theoretical, managerial and research implications are discussed. 


\section{LITERATURE REVIEW AND THEORETICAL FRAMEWORK}

\subsection{Resource-Based View and Organizational Capabilities}

Resource-based view theory (RBV) is based on the view that companies are heterogeneous since they have different resources and capabilities even if they operate in the same industry (Wright and McMahan, 1992); unlike positioning strategy (Porter, 1985), which suggests that firms are similar in terms of the strategic resources they have. Besides resource heterogeneity, RBV assumes that the resources have immobility, meaning that the resources cannot change hands unless the firms trade with each other (Peteraf, 1993). These are the resources that are losing their strategic functions once transferred to the other companies (Boxall, 1996). The bottom line is not only having the ownership of a particular resource, but rather; the main value-creating element is also having human capital, experienced employees who has required capabilities and are able to use these resources efficiently and effectively. By this way, individual resources gain an organizational manner.

According to the resource-based view, resources are of great importance in terms of achievement of a sustainable competitive advantage. Another issue that is as important as achieving a competitive advantage is to keep this competitive advantage in a long-term and sustainable manner. The reason is that existing resources and capabilities face with depreciation and become more likely to be imitated by competitors over time. As the resources can be separated as tangible and intangible resources (Barney, 1991), it is possible to say that it is easier to imitate tangible resources than the intangible ones. For this reason, intangible resources have a more critical value in achieving competitive advantage and capabilities are seen one of the most critical intangible assets of organizations.

While the resources are the main elements of production processes, they are not adequate enough to create value in an organization on their own. Another factor that is required for the use of these resources with the desired efficiency is the organizational capabilities (Kaleka, 2002). According to RBV, there is a close relationship between the resources and capabilities. Resources are important if they create the capabilities that will contribute to the growth and continuous development of an organization. In addition, resources can be imitated or transferred easier than capabilities, because capabilities are mostly based on implicit knowledge. The developments in capabilities have been examined by many researchers within the framework of the resource based view in time (Ulrich, 1989; Collis, 1991; Amit and Schoemaker, 1993; Teece and Pisano, 1994; Grant, 1996; Winter, 2000; Helfat and Peteraf, 2003). As Barney (1991) defines, capabilities as those organizational characteristics that 'enable an organization to conceive, choose and implement strategies'. In another definition made by Collis (1994), organizational capabilities are "socially complex routines that determine the efficiency with which firms physically transform inputs into outputs".

\subsubsection{Logistics Capability}

Logistics capability is one of the most critically important capabilities especially for manufacturing firms that enables acquiring a competitive advantage in this global economic environment with high competition (Xu and Wang, 2012). The role of logistics capabilities becomes even more critical, when quality-based competition is intense and time is a vital determinant (Gligor and Holcomb, 2014). Competition level has become very specific in today's world; and it is possible to say that many manufacturing companies are competing in supply-chain level (Christopher, 2000). Since price and promotion changes may be more quickly duplicated now, organizations focused on delivering customer value through logistics as a means of remaining competitive (Mentzer, Flint and Hult, 2001). As a main factor to distinguish and so make some of them more successful amongst others, logistics capability has a strategic aspect related to improvement of operational effectiveness as well as operational performance. In addition, successful logistics activities cannot be thought without having a sustainable and healthy communication provided by information systems within the organization with third parties related to activities outside of the organization. Unlike many operational and organizational capabilities, logistics capability depends on outside factors as well as inside effects. Logistics excellence has, therefore, become a powerful competence and source of competitive advantage for many firms and considered as a strategic resource that enables new strategic moves in the market (Esper, Fugate and Davis, 2007).

This capability has been categorized in different ways by many researches. Mentzer, Min and Bobbitt (2004) identify four broad categories, which are customer service and logistics quality, low cost distribution and low cost supply, information sharing and information technology and coordination capabilities (internal and external coordination capabilities. On the other hand; Cho, Ozment and Sink (2008) identify 11 logistics capabilities; presale customer service, post-sale customer service, delivery speed, responsiveness to target, widespread distribution coverage, global distribution coverage, selective distribution coverage, low total cost distribution, delivery reliability, delivery information communication, and web-based order handling. Morash, Dröge and Vickery (1996) offer an alternative categorization of logistics capabilities based on two value disciplines: demand or customeroriented approach and operations or supply-oriented approach. 


\subsubsection{Information Systems Capability}

Companies have to use of communication both individually and organizationally in order to align their beliefs, attitudes and behaviors within the organization with the aims of the organization and to achieve the desired performance targets. For this reason, there is a need for a continuous, scientific and systematic communication system for multidimensional and environmental relations. Today, information system mechanisms provide the information and communication that organizations need.

Information transfer can be in individual, group or organizational level. Information systems help creation of a system that enable this transfer in an accurate and effective way within an organization. By 1990s, information systems began to be examined under Resource-based view theory. Information systems capability affects all of the interactions occurring that are vital to the realization of activities. The importance of information systems capability increase as it also allows to the transfer of tacit knowledge which is one of the main dimensions of organizational learning. As well as enabling knowledge management; the process of obtaining, storing, sharing and using information, it is also related with technology and innovation management.

\subsection{Organizational Learning}

Organizations are learning by encoding inferences from history into routines that guide behavior. Routines are based on interpretations of the past and they adapt to experience incrementally in response to feedback about outcomes (Levitt and March, 1988). It is always important to minimize uncertainties and unwanted incidents as much as possible in business world, because the greater the uncertainty, the more risks are exposed to. In order to manage this situation in a way that will keep companies clear of, it is highly in parallel with the correct and successful management of information in companies. Information is at the center of organizational learning, and by organization theorists it is regarded as one of the most significant strategic resources that is important at effective control and management in organizations (Grant, 1996). According to Miller (2002), information is a critical intangible resource that creates value for organizations. It is also possible to evaluate information under the capital resources of an organization (Barney and Clark, 2007).

In the context of knowledge-based theory, information is divided into two parts. These are; explicit knowledge known by everyone which also easily transferable and implicit knowledge that is in the minds of individuals, which is not easily obtainable and difficult to imitate (as cited in Nonaka, 1994). The awareness of the information that individuals have as implicit knowledge only arises when they are asked to express this information. Implicit knowledge is inherently difficult to express and convey. While it is comparatively easy to transfer explicit knowledge in a written way, implicit knowledge can be transferred by the presentation of how to do something by showing the movements step by step (Hatch and Cunliffe, 2013). As Fahey and Prusak (1998) explains: "tacit knowledge is the means by which explicit knowledge is captured, assimilated, created and disseminated". Companies use integration mechanisms such as rules, guidelines, routines and procedures to avoid communication problems created by implicit knowledge. At this point, the importance of a successful information system capability is clear since it allows communicating and enabling the flow of information effectively.

Knowing the existence of something and knowing how it is done are two different things. Nonaka (1994) examines this distinction, which reveals how knowledge has emerged, how it's being used and how its functions differ, as the epistemological dimension of organizational knowledge. At the stage of knowledge formation, ideas gain an organizational dimension after they begin to form in the minds of individuals. In other words, it is not possible to create information that is independent from the employees in an organization. This explanation is expressed as the ontology of organizational knowledge formation.

What is aimed with organizational learning is the adoption of a culture based on creation and use of information spread across the whole organization in order to achieve competitive advantage. In addition to closely monitoring customer needs, changes in the market and competitors' activities, this process involves acquiring and sharing information to develop new technologies for superior positions and innovations for new production compared to competitors.

\section{RESEARCH METHOD}

\subsection{Sample and Data Collection}

In our study, we used easy sampling method in order to collect our survey data. We applied face-to-face surveys to our applicants. Responses to the survey questionnaire were assessed on a five-point Likert Scale. Survey of the study was applied on production sectors in Marmara Region in Turkey. And 353 companies were reached and 1035 usable surveys have been obtained. 
A big majority of the participants have a graduate degree and almost $65 \%$ of the companies are operating in international level. Companies are operating different manufacturing sectors, ranging from automotive to pharmaceutical and textile. Descriptive statistics of the respondents can be found in Table 1 .

Table 1: Descriptive Statistics of the Respondents

\begin{tabular}{|l|lll|}
\hline Level of Managers & Top Executives (5.4\%) & Medium Level Mn. (24.3\%) & White-Collar (70.4\%) \\
\hline Education Level & Post Graduate (19.1\%) & Graduate (63.5\%) & Undergraduate (17.4\%) \\
\hline \multirow{2}{*}{ Industries } & Food / Drink / Tobacco & Clothing / Textile & Chemicals / Petroleum \\
\hline & Automotive & Base Metal / Stone Based & Machinery / Technology \\
\cline { 2 - 4 } & Wood / Paper / Printing & Pharmaceutical / Medical Tech. & Elect. Mach. / Other Manuf. \\
\hline Field of Activity & Local (17.9\%) & National (18.1\%) & International (64.9\%) \\
\hline Gender & Men (57.8\%) & Women (42.2\%) & \\
\hline
\end{tabular}

\subsection{Research Model and Hypotheses}

This study is based on a field study where relationships between organizational learning, logistics capability and firm performance are explored as well as the mediating role of information systems capability on this relationship. We conducted this research on manufacturing companies that are operating industries such as; including automotive, machinery equipment \& metal goods, chemical \& petroleum, main metal and pharmaceutical sectors. We think that information systems capability and logistics capability are affected by organizational learning. In other words, organizational learning has a positive effect on these capabilities, which will also lead to a better logistics performance and so to a better firm performance. Research model and related hypotheses are as shown below.

Figure 1: Proposed Research Model

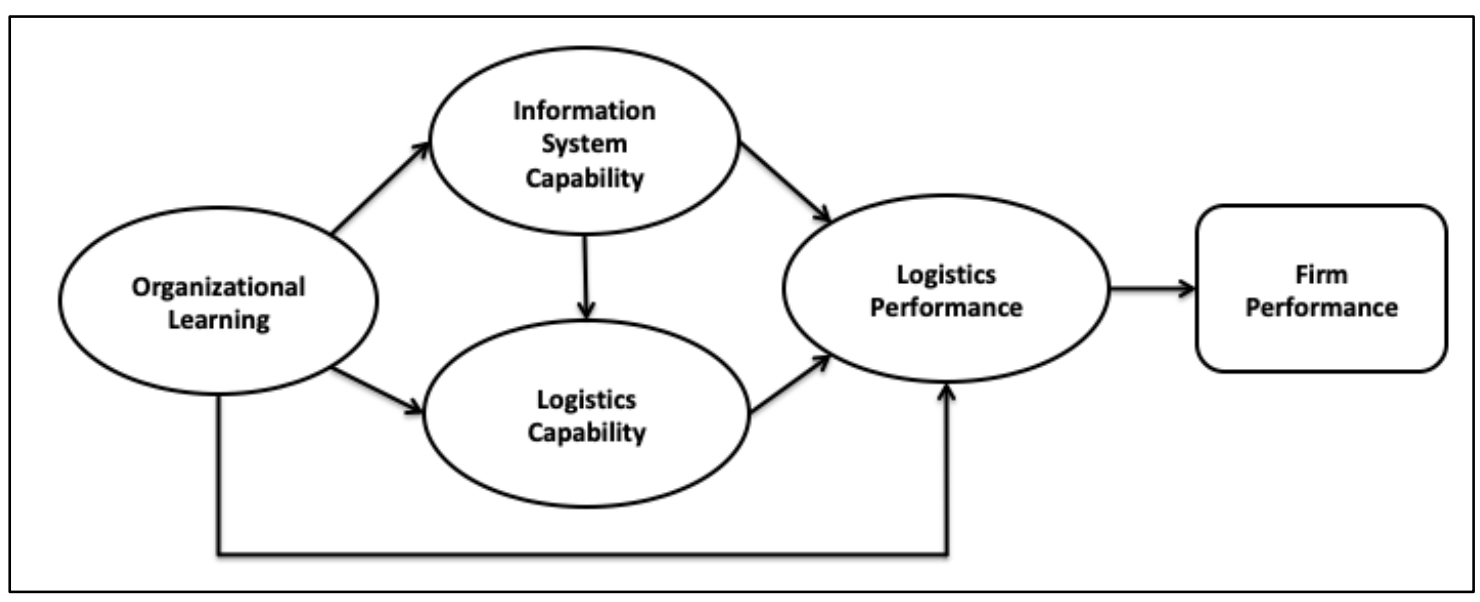

H1: Organizational learning positively affects information systems capability

H2: Organizational learning positively affects logistics capability

H3: Information systems capability has a mediating role on the relationship between organizational learning and logistics capability

H4: Organizational learning positively affects logistics performance

H5: Organizational learning positively affects firm performance through information systems capability, logistics capability and logistics performance 


\section{FINDINGS AND RESULTS}

\subsection{Analyses}

In our survey questions, Information systems capability, Organizational learning, Logistics capability scales developed by Acar and Zehir (2009), logistics performance scale was developed by Chow et al. (1994), firm performance scale was adopted by Baker and Sinkula (1999), Lynch et al. (2000), Antoncic and Hisrich (2001), Zahra et al. (2002) and are used in this research. Exploratory factor analysis (EFA) was conducted to see if the observed variables theoretically loaded together and reliability values were evaluated. And SPSS modeling technic has been used in testing the hypotheses.

Table 2: Coefficient Alfa, Means, Standard Deviations and Correlations

\begin{tabular}{|c|c|c|c|c|c|c|c|c|c|}
\hline & Means & SD & 1 & 2 & 3 & 4 & 5 & 6 & 7 \\
\hline 1. Number of Employees & 1790 & 5571 & & & & & & & \\
\hline 2. Year of Establishment & 1987 & 23,4 &,$- 442^{* *}$ & & & & & & \\
\hline 3. Info. Systems Capability & 3,94 & 0,54 &, $171^{* *}$ &,$- 140^{*}$ & $-0,877$ & & & & \\
\hline 4. Organizational Learning & 390 & 0,51 & 0,061 &,$- 142^{*}$ & $645^{* *}$ & $-0,938$ & & & \\
\hline 5. Logistics Capability & 3,83 & 0,54 & $151^{* *}$ &,$- 176^{* *}$ &, $557^{* *}$ & $640^{* *}$ & $-0,902$ & & \\
\hline 6. Logistics Performance & 3,83 & 0,61 & 0,081 &,$- 132^{*}$ & $472^{* *}$ &, $535^{* *}$ &, $588^{* *}$ & $-0,924$ & \\
\hline 7. Firm Performance & 3,73 & 0,56 & $138^{*}$ &,$- 115^{*}$ & $453^{* *}$ & $492^{* *}$ & $499^{* *}$ & $693^{* *}$ & $-0,949$ \\
\hline
\end{tabular}

${ }^{* *} p<0,01 ;{ }^{*} p<0,050$; Pearson Correlation. ${ }^{* *}$ Correlation is significant at the 0.01 level (2-tailed). Values in parenthesis are Cronbach's Alfa

Table 3: Exploratory Factor Analysis, Rotated Component Matrix

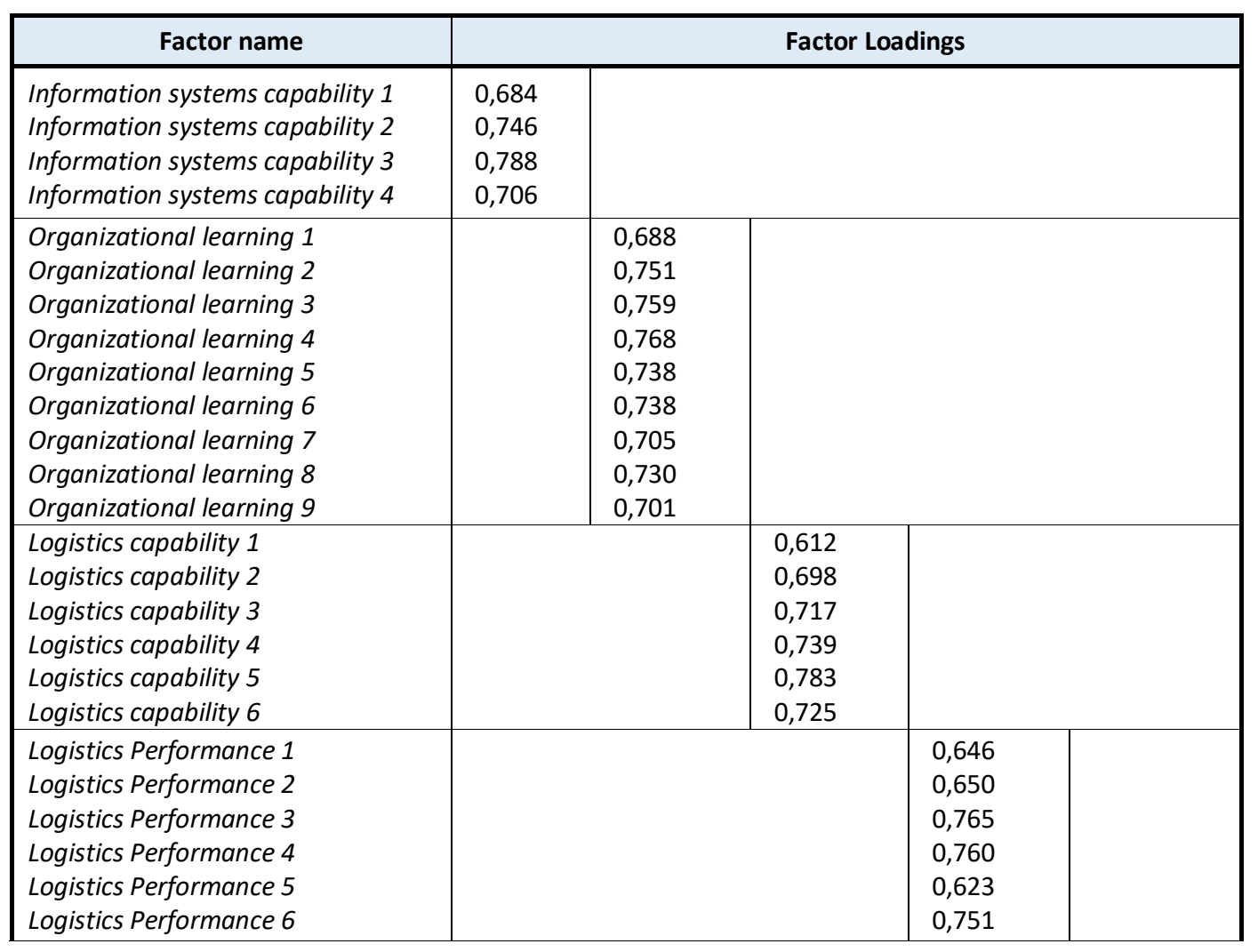




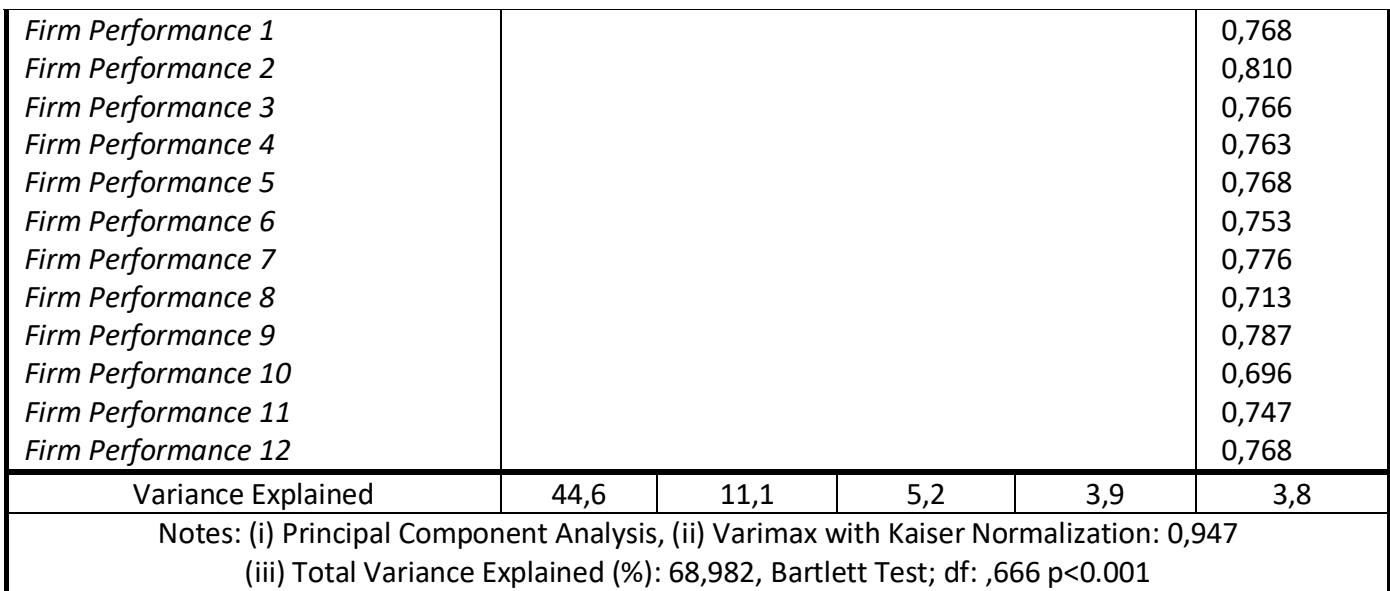

Correlation values between these variables are summarized in Table 2. As seen in the table there is not multicollinearity between dimensions. For the reliabilities of each factor, Chronbach's alpha values are calculated and shown in the table. For a good internal consistency, Chronbach's alpha value should be above 0.70 (Field, 2009) and all of the values are above this level.

When correlation results are examined, it is seen that all our hypotheses are accepted. Moreover, when the correlation relationship between demographic variables and research dimensions are examined it is confirmed that as employee numbers increase in an organization the perception regarding the availability of Information systems capability, Logistics capability, Logistics Performance and Firm Performance increases. This relationship is highest in the relationship with Information systems capability.

Exploratory factor analysis results related to the variables used in our study are given in Table 3 . The lowest value for factor loadings is accepted as 0.50 (Hair et al., 2010) as it can be seen from Table 3, all of the factor loadings are above the desired level. Total variance explained is $68,92 \%$ for our research.

\subsection{Results}

In this study, regression analysis is also conducted to test the hypotheses and to define the direction of relations. The results of our hypotheses are shown in Table 4. According to the results of our analysis, Organizational learning has a meaningful effect on Information systems capability (B; 629***, Adjusted R2: ,396, Sig: ,001) and also Logistics capability (B; 641***, Adjusted R2: ,409, Sig: ,001) , so $\mathrm{H} 1$ and $\mathrm{H} 2$ are accepted.

We also found the mediating role of Information systems capability on the relationship between Organizational learning and Logistics capability ( $\mathrm{B} ; 219 * * *$, Adjusted R2: ,433, Sig: ,001). As seen, this relationship is significant, so H3 is also accepted. The result of the forth hypothesis is also significant (B; 390***, Adjusted R2: ,392, Sig: ,001), so H4 is accepted. Finally, the results of H5 (B; 573***, Adjusted R2: ,504, Sig: ,001) also show that our last hypothesis is accepted. Besides, logistics performance has a mediating role on this relationship. One to one relationships between firm performance and other variables are shown in the correlation analysis. They are all statistically significant. To sum up, these results indicate that all of our hypotheses are accepted and the proposed model is valid.

Table 4: The Regression Results among Organizational Learning, Capabilities and Performance Variables

\begin{tabular}{|c|c|c|c|c|}
\hline $\begin{array}{l}\text { Independent } \\
\text { Variables }\end{array}$ & \multicolumn{3}{|c|}{ Mediator Variables and Dependent Variables } & Dependent Variables \\
\hline $\begin{array}{l}\text { Organizational } \\
\text { learning }\end{array}$ & $\begin{array}{l}\text { Information systems } \\
\text { capability }\end{array}$ & Logistics capability & Logistics Performance & Firm Performance \\
\hline $\begin{array}{l}\text { Organizational } \\
\text { learning }\end{array}$ & $\begin{array}{lc}\text {,629* } & \text { F: } 214,3 \\
* * & \text { Adj. R2: ,396 } \\
& \text { Sig: ,001 }\end{array}$ & & & \\
\hline
\end{tabular}




\begin{tabular}{|c|c|c|c|c|c|c|}
\hline $\begin{array}{l}\text { Organizational } \\
\text { learning }\end{array}$ & $\begin{array}{l}, 641^{*} \\
* * \\
\end{array}$ & $\begin{array}{c}\text { F:224,2 } \\
\text { Adj. R2: } \\
\text {,409 Sig: } \\
\text {,001 }\end{array}$ & & & & \\
\hline $\begin{array}{l}\text { Organizational } \\
\text { learning } \\
\text { Information systems } \\
\text { capability }\end{array}$ & $\begin{array}{l}, 499 * \\
* * \\
, 219 * \\
* *\end{array}$ & $\begin{array}{l}\text { F:124,1 } \\
\text { Adj. R2: } \\
\text {,433 Sig: } \\
\text {,001 }\end{array}$ & & & & \\
\hline $\begin{array}{l}\text { Organizational } \\
\text { learning } \\
\text { Information systems } \\
\text { capability }\end{array}$ & & & $\begin{array}{l}, 387^{* * *} \\
, 222 * * *\end{array}$ & $\begin{array}{l}\text { F: } 71,8 \\
\text { Adj. R2: } \\
\text {,306 } \\
\text { Sig: ,001 }\end{array}$ & & \\
\hline $\begin{array}{l}\text { Org. learning } \\
\text { Information systems } \\
\text { capability } \\
\text { Logistics capability }\end{array}$ & & & $\begin{array}{l}, 202^{* *} \\
, 127 * \\
, 390 * * * \\
\end{array}$ & $\begin{array}{c}\text { F:69,1 } \\
\text { Adj. R2: } \\
\text {,392 } \\
\text { Sig: ,001 } \\
\end{array}$ & & \\
\hline $\begin{array}{l}\text { Org. learning } \\
\text { Information systems } \\
\text { capability } \\
\text { Logistics capability }\end{array}$ & & & & & $\begin{array}{r}0,11 \\
, 240 * * * \\
, 283 * * *\end{array}$ & $\begin{array}{c}\text { F:46,4 } \\
\text { Adj. R2: } \\
\text {,301 } \\
\text { Sig: ,001 }\end{array}$ \\
\hline $\begin{array}{l}\text { Org. learning } \\
\text { Info. systems cap. } \\
\text { Logistics capability } \\
\text { Log. Performance }\end{array}$ & & & & & $\begin{array}{c}, 119 * \\
0,041 \\
0,063 \\
, 573^{* * *}\end{array}$ & $\begin{array}{l}\text { F:78,5 } \\
\text { Adj. R2: } \\
\text {,504 } \\
\text { Sig: , } 001\end{array}$ \\
\hline
\end{tabular}

$\left(* * * p<0,001 ;{ }^{* *} p<0,01,{ }^{*} p<0,050\right)$

\section{CONCLUSION AND DISCUSSION}

Logistics performance is one of the most important performance measures especially for manufacturing companies. Our study shows that managers, who want to have an excellence in logistics performance, should focus on creating an organization culture based on learning that is also supported by key capabilities. Logistics capability has a strategic aspect related to improvement of logistics effectiveness as well as firm performance overall. In addition, successful logistics activities cannot be thought without having a sustainable and healthy communication provided by information systems within the organization with third parties related to activities outside of the organization. Unlike many operational and organizational capabilities, logistics capability depends on outside factors as well as inside effects. Logistics excellence is a powerful competence and source of competitive advantage especially for manufacturing companies and considered as a strategic resource that enables new strategic moves in the market.

As an important part of the operation side in companies, information systems capability plays a crucial role. Information systems help creation of a system that enable this transfer in an accurate and effective way within an organization. Each activity is linked with another one in companies. In order to have a smooth operational cycle, there must be a strong infrastructure system, which is always supported by updated and innovative solutions. This capability affects all of the interactions occurring that are vital to the realization of activities. The importance of information systems capability increase as it also allows to the transfer of tacit knowledge, which is one of the main dimensions mentioned in organizational learning. Our research shows that a successful firm performance is dependent on a successful logistics performance. In order to achieve this, companies not only must be learning oriented, but also must provide strong information systems capability as well as logistics capability.

There are a few limitations of this study. This survey is conducted on companies that are operating in manufacturing sector in Turkey. Moreover, this survey is conducted on a limited number of sectors- only on production sectors- that is why findings might not be transferable to all types of sectors and organizations. Thus, further researches can be conducted on other sectors and, also in different countries for the generalizability of findings. 


\section{REFERENCES}

Acar, Z. A. and Zehir, C. (2009). Development and validation of a multidimensional business capabilities measurement instrument. Journal of Transnational Management, 14(3), 215-240.

Agarwal, R., Krudys, G. and Tanniru, M. (1997). Infusing learning into the information systems organization. European Journal of Information Systems, 6(1), 25-40.

Amit, R. and Schoemaker, P.J.H. (1993). Strategic Assets and Organizational Rents. Strategic Management Journal, 14, 33-46.

Andreu, R. and Ciborra, C. (1996). Organisational learning and core capabilities development: the role of IT. The Journal of Strategic Information Systems, 5(2), 111-127.

Antoncic, B. and Hisrich, R. D. (2001). Intrapreneurship: Construct refinement and cross-cultural validation. Journal of business venturing, 16(5), 495-527.

Argyris, C. and Schon D. (1978). Organizational Learning. Addison- Wesley, London.

Baker, W. E. and Sinkula, J. M. (1999). The synergistic effect of market orientation and learning orientation on organizational performance. Journal of the academy of marketing science, 27(4), 411-427.

Bapuji, H. and Crossan, M. (2004). From questions to answers: reviewing organizational learning research. Management learning, 35(4), 397-

417.

Barney, J. B. (1991), 'Firm Resources and Sustained Competitive Advantage', Journal of Management, Vol 17; s 112.

Barney, J. B. and Clark, D. N. (2007). Resource-Based Theory: Creating and Sustaining Competitive Advantage, Oxford: Oxford University Press.

Bell, J. E., Bradley, R. V., Fugate, B. S. and Hazen, B. T. (2014). Logistics information system evaluation: Assessing external technology integration and supporting organizational learning. Journal of Business Logistics, 35(4), 338-358.

Boxall, P. (1996). The strategic HRM debate and the resource-based view of the firm. Human resource management journal, 6(3), 59-75.

Canessa-Terrazas, E. C., Morales-Flores, F. J. and Maldifassi-Pohlhammer, J. O. (2017). The impact of IT-enhanced organizational learning on performance: evidence from Chile. Revista Facultad de Ingeniería Universidad de Antioquia, (82), 60-67.

Celuch, K. G., Kasouf, C. J. and Peruvemba, V. (2002). The effects of perceived market and learning orientation on assessed organizational capabilities. Industrial marketing management, 31(6), 545-554.

Cho, J.J.K, Ozment, J. and Sink, H. (2008). Logistics capability, logistics outsourcing and firm performance in an e-commerce market. International journal of physical distribution \& logistics management, 38(5), 336-359.

Christopher, M. (2000). The Agile Supply Chain. Industrial Marketing Management 29 (1): 37-44.

Collis, D. J. (1994). Research note: how valuable are organizational capabilities?. Strategic management journal, 15(S1), 143-152.

Chow, G., Heaver, T. D. and Henriksson, L. E. (1994). Logistics performance: definition and measurement. International journal of physical distribution \& logistics management, 24(1), 17-28.

Esper, T. L., Fugate, B. S. and Davis-Sramek, B. (2007). Logistics learning capability: sustaining the competitive advantage gained through logistics leverage. Journal of Business Logistics, 28(2), 57-82.

Fahey, L. and Prusak, L. (1998). The eleven deadliest sins of knowledge management. California management review, 40(3), 265-276.

Field, A. (2009). Discovering Statistics Using Spss (3rd Ed.). London: Sage.

Fiol, C. and Lyles, M. (1985). Organizational Learning. The Academy of Management Review, 10(4), 803-813. Retrieved from http://www.jstor.org/stable/258048.

Gligor, D. M. and Holcomb, M. C. (2014). Antecedents and consequences of integrating logistics capabilities across the supply chain. Transportation Journal, 53(2), 211-234.

Grant, R.M. (1996). Prospering in dynamically-competitive environments: organizational capability as knowledge integration. Organizational Science 7, 375-87.

Hair, J. F. J., Black, W. C., Babin, B. J. and Anderson, R. E. (2010). Multivariate Data Analysis. Seventh Edition Prentice Hall.

Hatch, M. J. and Cunliffe, A. L. (2013). Organization theory: modern, symbolic and postmodern perspectives. Oxford university press.

Helfat, C.E. and Peteraf, M.A. (2003). The Dynamic Resource-Based View: Capability Lifecycles. Strategic Management Journal, 24, $997-1010$. 
Kaleka, A. (2002). Resources and capabilities driving competitive advantage in export markets: guidelines for industrial exporters. Industrial Marketing Management, 31(3), 273-283.

King, W. R. (2006). The critical role of information processing in creating an effective knowledge organization. Journal of Database Management (JDM), 17(1), 1-15.

Levitt, B. and March, J.G. (1988). Organizational learning. Annual Review of Sociology, 14, 319-340.

Lynch, D. F., Keller, S. B. and Ozment, J. (2000). The effects of logistics capabilities and strategy on firm performance. Journal of business logistics, 21(2), 47.

Mentzer, J. T., Flint, D. J. and Hult, G. T. M. (2001). Logistics service quality as a segment-customized process. Journal of Marketing, 65, 82-104.

Mentzer, J. T., Min, S. and Michelle Bobbitt, L. (2004). Toward a unified theory of logistics. International Journal of Physical Distribution \& Logistics Management, 34(8), 606-627.

Morash, E. A., Droge, C. L. and Vickery, S. K. (1996). Strategic logistics capabilities for competitive advantage and firm success. Journal of business Logistics, 17(1), 1.

Nelson, R. R. and Sidney G. W. (1982). An Evolutionary Theory of Economic Change. Belknap Press/Harvard University Press: Cambridge.

Nonaka, I. (1994). A dynamic theory of organizational knowledge creation. Organization science, 5(1), 14-37.

Porter, M. E. (1985). Competitive Advantage-Creating And Sustaining Superior Performance. The Free Press, New York.

Santos-Vijande, M. L., López-Sánchez, J. Á. and Trespalacios, J. A. (2012). How organizational learning affects a firm's flexibility, competitive strategy, and performance. Journal of Business Research, 65(8), 1079-1089.

Teece, D. and Pisano, G. (1994). The dynamic capabilities of firms: an introduction. Industrial and corporate change, 3(3), 537-556.

Tippins, M. J. and Sohi, R. S. (2003). IT competency and firm performance: is organizational learning a missing link?. Strategic management journal, 24(8), 745-761.

Ulrich, D. (1989). Gaining Strategic and Organizational Capability in a Turbulent Business Environment, The Academy of Management Executive, Vol. III (2), pp. 115-122.

Winter, S.G. (2000). The Satisficing Principle in Capability Learning. Strategic Management Journal. 21(10-11): 981-996.

Wright, P. M. and McMahan, G. C. (1992). Theoretical perspectives for strategic human resource management. Journal of management, 18(2), 295-320.

Xu, L. and S. Wang. (2012). "Empirical Research on Construct of Chain Store Logistics Capability System.” I-Business 4 (1): 10-17.

Zahra, S. A., Neubaum, D. O. and El-Hagrassey, G. M. (2002). Competitive analysis and new venture performance: Understanding the impact of strategic uncertainty and venture origin. Entrepreneurship Theory and Practice, 27(1), 1-28. 